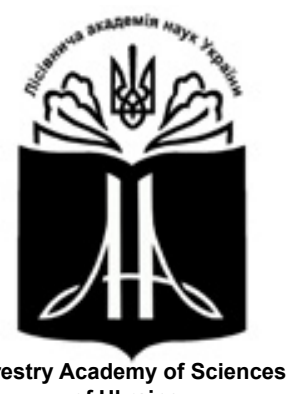

of Ukraine

Наукові праці Лісівничої академії наук України Proceedings of the Forestry Academy of Sciences of Ukraine

http://fasu.nltu.edu.ua https://doi.org/10.15421/411910

Article received 2018.09.27

Article accepted 2019.03.28
ISSN 1991-606X print

ISSN 2616-5015 online

(a) $\triangle$ Correspondence author

Petro Lakyda

lakyda@nubip.edu.ua

Heroyiv Oborony st., 15, Kyiv, 03041, Ukraine

УДК 633.877.3;630*2(292.486)

\title{
Нормативи оцінки продуктивності крони соснових деревостанів в умовах Північного Степу України
}

\author{
П.І. Лакида', В.М. Ловинська²
}

Наведено результати оцінювання фітомаси компонентів крони соснових деревостанів в умовах Північного Степу Украӥни. Сформовано робочий масив даних для соснових деревостанів із врахуванням таксаційних показників та фітомаси структурних компонентів крони. Охарактеризовано закономірності статистичного розподілу фітомаси деревної зелені у свіжозрубаному стані, фітомаси гілок та фітомаси хвої в абсолютно сухому стані. Подано результати корелячійного аналізу компонентів фітомаси крони модальних деревостанів із основними таксаиійними показниками насаджень. Найтісніший прямий кореляційний зв'язок простежено між фітомасами деревної зелені, гілок та хвої з показником відносної повноти деревостанів. Виявлено прямий достовірний, середньої сили зв'язок фітомаси гілок деревостану в абсолютно сухому стані із середнім діаметром насаджень. Побудовано регресійні математичні моделі для оцінки фітомаси компонентів параметрів крони, в яких вхідними аргументами є середній діаметр, середня висота та відносна повнота деревостанів. Коефіиієнти детермінації для отриманих моделей знаходяться у межах від 0,69 до 0,74. Усі розроблені моделі демонструють прямий позитивний зв'язок між фітомасою будь-якого структурного компонента крони деревостану із середнім діаметром та відносною повнотою насадження, тоді як із висотою деревостану зв'язок є оберненим. Наведено нормативні таблиці для оцінки фітомаси деревної зелені, гілок та хвої, значення яких збільшується зі збільшенням середнього діаметра, тоді як зі збільшенням середньої висоти насадження іде на спад. Проведено порівняльний аналіз показників фітомаси компонентів стовбура соснових деревостанів із результати досліджень, встановленими для іниих природно-кліматичних зон України.

Ключові слова: Pinus sylvestris L.; модель фітомаси деревостану; деревна зелень; гілки; хвоя; Дніпропетровська область.

Вступ. Кіотський протокол, який було прийнято у 1997 р., став першим важелем світового масштабу, в якому порушено питання боротьби із антропогенною зміною клімату на глобальному рівні. Цей документ зобов' язав наукове співтовариство розробити стратегію компенсації промислових викидів біологічною фіксацією атмосферного вуглецю як основного біогена планети і стимулював перший крок людства в напрямку пізнання біології глобаль- ного вуглецевого циклу. Щоб зменшити економічне навантаження на глобальну проблему зміни клімату, економічна кліматична політика має мотивувати заходи щодо пом'якшення клімату в порядку витрат, починаючи 3 найдешевших, а після цього переходити до дорожчих заходів (Pohjola et al., 2018).

Поглинання вуглецю лісовими насадженнями відіграє ключову роль в аспекті впровадження подібних заходів, адже істотне скорочення викидів

Лакида Петро Іванович - академік Лісівничої академії наук України, професор, доктор сільськогосподарських наук, директор навчально-наукового інституту лісового і садово-паркового господарства НУБіП України. Національний університет біоресурсів та природокористування України, вул. Героїв Оборони, 15, м. Київ, 03041, Україна. Тел.: (044) 527-85-28, +38-067-462-80-43. E-mail: lakyda@nubip.edu.ua ORCID: https://orcid.org/0000-0003-3639-2969

2 Ловинська Вікторія Миколаївна - кандидат біологічних наук, доцент кафедри садово-паркового господарства. Дніпровський державний аграрно-економічний університет, вул. С. Єфремова, 25, м. Дніпро, 49060, Україна. Тел.: +38-067-769-63-29; E-mail: glub@ukr.net ORCID: http://orcid.org/ 0000-0002-7359-9443 
діоксиду вуглецю може бути отримано за відносно низьких витрат (Vass \& Elofsson, 2016).

Біологічну продуктивність лісів розглядають як їх основну характеристику, що визначає перебіг процесів у лісових екосистемах і використовують для екологічного моніторингу за сталого ведення лісового господарства. Моделювання продуктивності лісів обов'язково здійснюють 3 урахуванням глобальних змін клімату, із вивченням структури та біорізноманіття лісового насадження, оцінкою вуглецедепонувальних властивостей лісів тощо (Fowler et al., 2002, Grote \& Reiter, 2004, Fernández et al., 2011, Rogozin \& Razin, 2015, Faraway, 2016).

Надання інформації щодо комплексної оцінки фітомаси насаджень $\epsilon$ обов'язковою умовою у процесі виконання програм із моніторингу лісів (Turski et al., 2008, He et al., 2013). Значна кількість робіт, що здійснюється у цьому напрямі, характеризується комплексним підходом під час оцінки основних складників біологічної продуктивності з використанням при цьому біометричних і статистичних методів (Usoltsev, 2005, 2007, Lakyda, 2002).

Розвиток крони дерев супроводжується приростом їх асиміляційної частини та гілок і наступною диференціацією дерев у насадженні (Lakyda et al., 2012, Basuki, 2015). На ріст і розвиток дерева i, зокрема, гілок, листя (хвої) впливають кліматичні, едафічні, біотичні, антропогенні чинники (Barthélémy \& Caraglio, 2007, Goodman et al., 2014). Саме від них залежать показники фітомаси крони (сумарна маса всіх живих гілок крони з листям (хвоєю), у тому числі двійчаток, пасинків), які навіть у дерев одного виду й одного віку можуть відрізнятись, і з цієї причини важко піддаються обліку і прогнозуванню їхньої динаміки (Hasenauer \& Monserud, 1996, Lakyda \& Matushevich, 2006, Mäkelä \& Valentine, 2006, Poudel et al., 2015).

Сосна звичайна $є$ одним із найневибагливіших деревних видів до умов навколишнього середовища, але водночас і найбільш господарсько цінною деревною породою. Поєднання невибагливості сосни до лісорослинних умов, швидкий ріст, значні запаси стовбурової деревини і виходу ділових сортиментів $\epsilon$ причиною того, що саме ця порода $\epsilon$ найпоширенішою в Європі загалом та в Україні зокрема (Krakau et al., 2013, Tóth et al., 2017). Сосна $\epsilon$ головною лісотвірною породою і в степовій зоні України, а у межах Дніпропетровської обл. формує деревостани на площі 24,6\% вкритих лісовою рослинністю лісових ділянок.

Проаналізувавши літературні джерела щодо стану вивчення біопродуктивності соснових насаджень різних регіонів України, не виявлено подібної інформації для сосняків Північного Степу України. 3 огляду на це актуальним є питання побудови моделей та розроблення нормативнодовідникового забезпечення фітомаси компонентів деревостанів сосни звичайної, які ростуть у межах Дніпропетровського регіону.

Матеріали й методи. Об'єктом дослідження стали деревостани сосни звичайної в умовах Пів- нічного Степу України. Предмет дослідження біопродуктивність компонентів крони соснових деревостанів Північного Степу України. Мета дослідження - розробити моделі та нормативи оцінки компонентів фітомаси крони деревостанів сосни звичайної для досліджуваного регіону.

Оцінку біологічної продуктивності за компонентами фітомаси крони соснових насаджень проводили шляхом поєднання емпіричних і теоретичних методів. Всього закладено 20 тимчасових пробних площах (ТПП) у межах лісового фонду державних підприємств Дніпровського обласного управління лісового i мисливського господарства. Під час польових та лабораторнокамеральних досліджень використовували апробовану для таких цілей методику (Lakyda, 2002). Відбір модельних дерев (МД) на ТПП здійснювали за принципом ї репрезентативності до розподілу за ступенями товщини 3 урахуванням значень висот дерев. Результати вимірювань відібраних випадковим способом на модельних деревах модельних гілок (фракція деревної зелені) 3 нижньої, серединної та верхівкової частин крони, використано для визначення частки хвої у фракції деревної зелені та вмісту сухої речовини у хвої. Для дослідження показників щільності деревини та кори гілок крони використовували спеціальну формулу (Lakyda, 2002).

Статистичне оброблення даних та пошук багатомірних регресійних моделей результатів досліджень здійснено за допомогою Excel та програми STATISTICA 10 (Stat Soft Inc., 2011). Спеціальне оброблення дослідних даних виконано за допомогою прикладних програм PERTA, ZRIZ, PLOT, пов'язаних із кількісною та якісною оцінкою компонентів фітомаси крони деревостану (Lakyda, 2002).

Сформовано робочий масив даних таксаційних показників для соснових деревостанів із врахуванням таких характеристик: середній діаметр $(D)$, середня висота $(H)$, фітомаса деревної зелені у свіжозрубаному стані $\left(P h_{\partial_{z}}\right)$, фітомаса гілок в абсолютно сухому стані $\left(P h_{\text {zin }}\right)_{3}$, фітомаса хвої в абсолютно сухому стані $\left(P h_{x \in}\right)$ i таксаційний показник тимчасових пробних площ - відносна повнота $(P)$ деревостану. Віковий діапазон досліджуваних деревостанів становив 9-87 років, а варіювання відносних повнот виявилось досить широким i становило 0,13-1,04. Алгоритм обробки даних включав їх статистичне оброблення, кореляційний аналіз, пошук регресійних залежностей та розробку нормативів компонентів фітомаси крони сосни звичайної залежно від таксаційних показників деревостану.

Результати досліджень. Для встановлення адекватності моделей з визначення фітомаси компонентів крони, було виконано статистичний аналіз із розрахунком мінімального ( $\mathrm{min}$ ) та максимального (max) значень, середнього арифметичного показника $(\dot{X})$, середнього квадратичного відхилення $(\sigma)$, асиметрії $(A)$ та ексцесу $(E)$ (табл. 1).

За результатами розподілу біометричних показників та компонентів фітомаси крони, в усіх випадках 
виявлено їх невідповідність нормальному розподілу через перевищення критичного значення асиметрії $\left(A_{\text {кр }}-0,723\right)$, окрім показників середньої висоти та відносної повноти деревостану. Також встановлено перевищення критичного значення ексцесу розподілів $\left(E_{\text {кр }}-0,843\right)$ у випадках розподілів як фітомаси деревної зелені, гілок, так і хвої деревостанів. Криві розподілів фітомаси усіх компонентів крони характеризуються гостровершинністю. Біометричні пара- метри сосняків (крім повноти) характеризуються лівосторонньою асиметрією, туповершинністю кривої розподілу ексцесу для середнього віку деревостану та гостровершинністю значень середніх показників діаметра, висоти та відносної повноти.

Для визначення тісноти зв'язку компонентів фітомаси крони соснових деревостанів з їх основними таксаційними характеристиками здійснено кореляційний аналіз, результати якого наведено у табл. 2.

\section{Статистична характеристика розподілу таксаційних показників та компонентів} фітомаси крони деревостанів сосни звичайної

\begin{tabular}{|c|c|c|c|c|c|c|}
\hline \multirow{2}{*}{ Ознака } & \multicolumn{2}{|c|}{ Значення } & \multicolumn{4}{|c|}{ Статистики } \\
\hline & $\min$ & $\max$ & $\dot{X}$ & $\Sigma$ & $A$ & $E$ \\
\hline$D_{1,3}, \mathrm{~cm}$ & 4,6 & 40,2 & 21,8 & 8,0 & $-0,416$ & 1,604 \\
\hline$H, \mathrm{~m}$ & 2,8 & 30,5 & 19,4 & 7,2 & $-1,005$ & 1,225 \\
\hline$P$ & 0,13 & 1,04 & 0,56 & 0,17 & 0,349 & 3,803 \\
\hline$P h_{\partial 3 .}, \mathrm{T} \cdot \Gamma \mathrm{a}^{-1}$ & 2,0 & 39,7 & 11,3 & 8,7 & 1,786 & 4,904 \\
\hline$P h_{\text {гілл }}, \mathrm{\tau} \cdot \mathrm{га}^{-1}$ & 0,68 & 22,3 & 6,5 & 5,1 & 1,490 & 3,604 \\
\hline$P h_{x \in}, \mathrm{\tau}^{\cdot} \mathrm{га}^{-1}$ & 0,68 & 12,4 & 3,5 & 2,8 & 1,892 & 4,337 \\
\hline
\end{tabular}

Коефіціснти кореляції компонентів фітомаси крони деревостанів сосни звичайної з їх таксаційними ознаками

\begin{tabular}{|c|c|c|c|c|c|c|}
\hline Показник & $D_{l, 3}, \mathrm{~cm}$ & $H, \mathrm{M}$ & $P$ & $P h_{\partial 3}, \mathrm{~s} \cdot \mathrm{ra}^{-1}$ & $P h_{\text {zin }}, \mathrm{\tau} \cdot \mathrm{ra}^{-1}$ & $P h_{x \in}, \mathrm{\tau} \cdot \mathrm{ra}^{-1}$ \\
\hline$D_{1,3}, \mathrm{~cm}$ & 1 & - & - & - & - & - \\
\hline$H, \mathrm{м}$ & 0,92 & 1 & - & - & - & - \\
\hline$P$ & 0,35 & 0,34 & 1 & - & - & - \\
\hline$P h_{\partial 3}, \mathrm{\tau} \cdot \mathrm{ra}^{-1}$ & 0,44 & 0,31 & 0,72 & 1 & - & - \\
\hline$P h_{\text {гіл }}$, т.га $\mathrm{a}^{-1}$ & 0,45 & 0,31 & 0,69 & 0,97 & 1 & - \\
\hline$P h$, т.га ${ }^{-1}$ & 0,38 & 0,26 & 0,71 & 0,98 & 0,94 & 1 \\
\hline
\end{tabular}

Аналіз результатів коефіцієнтів кореляції виявив прямий достовірний середньої сили зв'язок фітомаси гілок деревостану із середнім діаметром насаджень. Наявність прямого високого за тіснотою зв'язку відзначено у варіантах між фітомасами усіх компонентів крони і відносною повнотою насадження. Кореляційні зв'язки між фітомасою деревної зелені, фітомасою гілок, фітомасою хвої 3 висотою деревостану виявились лінійними, однак низькими та незначимими на 5\%-му рівні.

Пошук математичних моделей взаємозв'язку компонентів фітомаси крони соснових деревостанів регіону досліджень із основними таксаційними характеристиками насаджень здійснювали за допомогою методу прямої регресії. При цьому як аргументи регресійних залежностей були середній діаметр, середня висота та відносна повнота насаджень.

Отже, для прямої регресії використовували таку алометричну залежність:

$$
P h_{i}=f(D, H, P) \text {, }
$$

де $P h_{i}-$ відповідні компоненти крони фітомаси деревостанів сосни звичайної, т·га ${ }^{-1}$;

$f(D, H, P)$ - функції відповідних таксаційних ознак деревостану.
Значущість впливу аргументів на досліджувану фітомасу компонентів крони оцінювали на 5\%-му рівні за довірчими інтервалами коефіцієнтів регреciï. Потрібно зазначити, що введення у регресійні рівняння такого фактора впливу, як відносна повнота насадження, який мав тісний кореляційний зв'язок із усіма компонентами фітомаси крони, дало змогу значно покращити статистичні параметри адекватності побудованих моделей. Отже, внаслідок багатоваріантного пошуку, відібрано регресійні моделі, які рекомендовано для побудови нормативних таблиць оцінки надземної фітомаси компонентів крони соснових деревостанів для досліджуваного регіону (табл. 3).

Наведені моделі адекватно описують дослідні дані, про що свідчать досить високі значення коефіцієнтів детермінації $\left(\mathrm{R}^{2}=0,69-0,74\right)$. В усіх розроблених рівняннях спостерігається прямий зв'язок між фітомасою будь-якого компоненту крони деревостану із середнім діаметром та відносною повнотою насадження, тоді як з висотою деревостану зв'язок є оберненим. Це узгоджується із результатами досліджень інших авторів, які зазначають, що зі збільшенням середньої висоти деревостану, але за 
однакових значень середнього діаметра та відносної повноти, процес нагромадження біопродукції крони у насадженнях уповільнюється (Bilous, 2010, Lakyda et al., 2013).

Оцінювання фітомаси гілок в абсолютно сухому стані, хвої в абсолютно сухому стані, деревної зелені у свіжозрубаному стані проводили з урахуванням таких показників: базисної щільності гілок у корі (417 кг· $\left.\left(\mathrm{M}^{3}\right)^{-1}\right)$; вмісту абсолютно сухої речовини у хвої $(0,520)$; частки хвої у деревній зелені $(59,6 \%)$.

Моделі для оцінки фітомаси компонентів крони стали підгрунтям для практичного їх втілення в розроблення нормативно-довідникового забезпечення соснових модальних деревостанів із використанням трьох змінних - середнього діаметра, середньої висоти та відносної повноти насадження. Варіювання середніх діаметрів деревостанів спостережено в межах від 4 до $30 \mathrm{~cm}$, середніх висот - від 4 до 28 м, відносних повнот - від 0,6 до 0,9 .

Фрагмент нормативних таблиць (відносна повнота модальних деревостанів 0,8) для оцінки фітомаси крони сосняків у досліджуваному регіоні наведено у табл. 4.

Табличя 3

Моделі для оцінювання компонентів фітомаси крони деревостанів сосни звичайної

\begin{tabular}{ccc}
\hline Номер моделі & Вид рівняння & Коефіцієнт детермінації \\
\hline 1 & $P h_{\text {zіл. }}=1,335 \cdot D^{1,702} \cdot H^{-0,983} \cdot P^{1,443}$ & 0,71 \\
2 & $P h_{x \varepsilon .}=1,136 \cdot D^{1,212} \cdot H^{-0,582} \cdot P^{1,702}$ & 0,69 \\
3 & $P h_{\partial 3}=2,312 \cdot D^{1,362} \cdot H^{-0,599} \cdot P^{1,604}$ & 0,74 \\
\hline
\end{tabular}

Фітомаса крон дерев соснових деревостанів, т·га ${ }^{-1}$

\begin{tabular}{|c|c|c|c|c|c|c|c|c|c|c|c|c|c|}
\hline \multirow{2}{*}{$\begin{array}{c}\text { Середній } \\
\text { діаметр, см }\end{array}$} & \multicolumn{13}{|c|}{ Середня висота, м } \\
\hline & 4 & 6 & 8 & 10 & 12 & 14 & 16 & 18 & 20 & 22 & 24 & 26 & 28 \\
\hline \multicolumn{14}{|c|}{ Відносна повнота насаджень 0,8} \\
\hline 4 & 4,5 & 3,2 & & & & & & & & & & & \\
\hline 6 & 8,3 & 5,9 & 4,7 & & & & & & & & & & \\
\hline 8 & & 9,1 & 7,2 & 6,0 & 5,2 & & & & & & & & \\
\hline 10 & & & 10,1 & 8,4 & 7,2 & 6,4 & & & & & & & \\
\hline 12 & & & 13,3 & 11,0 & 9,5 & 8,4 & 7,5 & & & & & & \\
\hline 14 & & & & 14,0 & 12,0 & 10,5 & 9,4 & 8,6 & 7,9 & & & & \\
\hline 16 & & & & & 14,7 & 12,9 & 11,6 & 10,5 & 9,6 & 8,9 & & & \\
\hline 18 & & & & & & 15,5 & 13,8 & 12,5 & 11,5 & 10,6 & 9,9 & & \\
\hline 20 & & & & & & & 16,2 & 14,7 & 13,5 & 12,4 & 11,6 & & \\
\hline 22 & & & & & & & & 17,0 & 15,6 & 14,4 & 13,4 & & \\
\hline 24 & & & & & & & & & 17,8 & 16,4 & 15,3 & 14,3 & \\
\hline 26 & & & & & & & & & & 18,5 & 17,2 & 16,1 & 15,2 \\
\hline 28 & & & & & & & & & & & 19,3 & 18,0 & 17,0 \\
\hline 30 & & & & & & & & & & & & 20,0 & 18,8 \\
\hline
\end{tabular}

За результатами дослідження, фітомаса деревної зелені, гілок та хвої деревостанів сосни звичайної збільшується зі зростанням середніх діаметрів насаджень. Однак зі збільшенням висоти дерев у межах одного діаметра, фітомаса компонентів крон соснових деревостанів спадає.

За результатами аналізу фітомаси крон сосняків за їх структурними частинами виявлено поступове зменшення фітомаси хвої із збільшенням віку деревостанів (рис. 1). Так, у дерев 3 діаметром 30 см, порівняно 3 екземплярами діаметром $8 \mathrm{~cm}$, частка хвої у кроні зменшується на $5 \%$ із відповідним збільшенням частки гілок, що узгоджується із постулатами біологічної природи формування крони сосни звичайної у насадженні із віком. Подібні тенденції змін структури крони дослідники визначили для деревних порід інших природних зон України (Lakyda, 2002, Bilous, 2010).

Важливим етапом проведених досліджень є порівняння отриманих даних із результатами досліджень інших науковців, які опрацьовували отримані результати за аналогічними методиками. Однак на сьогодні немає нормативів, розроблених подібним способом для соснових деревостанів, що ростуть в умовах Північного Степу України. 3 огляду на це, отримані дані порівнювали із результатами, знайденими для деревостанів сосни звичайної інших природних зон України (рис. 2). 


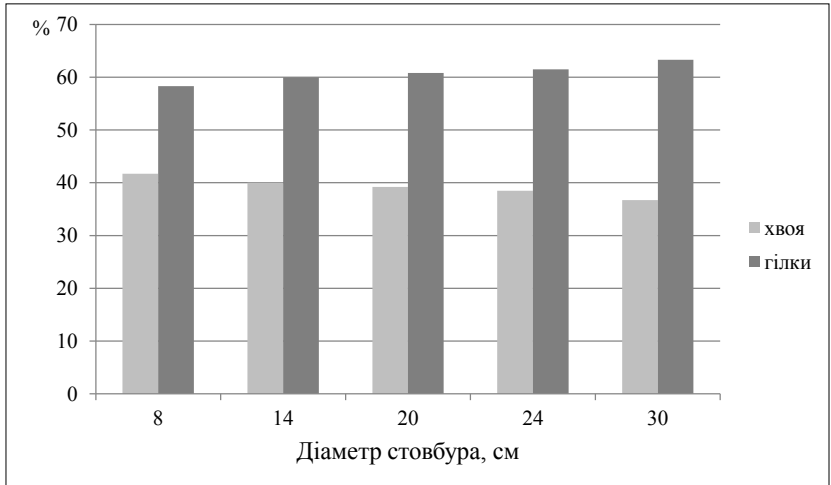

Рис. 1. Зміна структури фітомаси крони сосняків залежно від діаметра дерев (відносна повнота модальних деревостанів 0,8): при $\mathrm{D}=8 \mathrm{~cm}, \mathrm{H}=10 \mathrm{м} ; \mathrm{D}=14 \mathrm{~cm}, \mathrm{H}=16 \mathrm{м}$; $\mathrm{D}=20 \mathrm{~cm}, \mathrm{H}=22 \mathrm{~m} ; \mathrm{D}=24 \mathrm{~cm}, \mathrm{H}=26 \mathrm{~m} ; \mathrm{D}=30 \mathrm{~cm}, \mathrm{H}=28 \mathrm{~m}$
Отже, порівняно із сосновими деревостанами зони Полісся та Лісостепу (Lakyda, 2002), значення фітомаси хвої та гілок в абсолютно сухому стані $є$ нижчими за однакових діаметрів (у цьому випадку 16 см). Окрім цього, зафіксовано сильнішу інтенсивність спадання величини фітомаси гілок зі зростанням середньої висоти деревостану, отриманих за результатами наших досліджень, порівняно із раніше отриманими даними для Полісся та Лісостепу. Відмінність отриманих результатів, насамперед, пояснюють різними географічними зонами, а нижчі показники фітомаси окремих компонентів крони в умовах степової зони свідчать про менш сприятливі кліматичні умови росту для деревостанів сосни звичайної у досліджуваному регіоні.

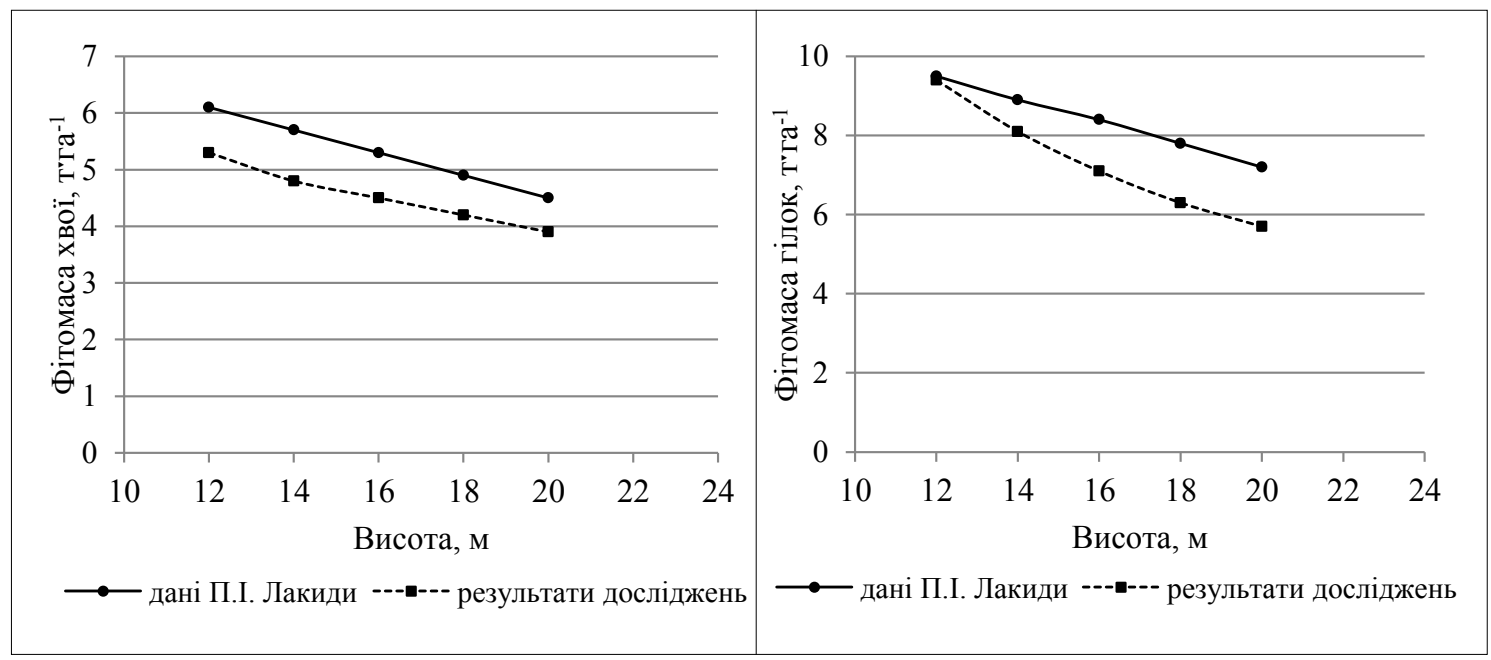

Рис. 2. Зміна фітомаси хвої та гілок в абсолютно сухому стані залежно від середньої висоти за сталого середнього діаметра насадження (16 см)

Висновки. За результатами статистичного аналізу, криві розподілів фітомаси усіх досліджуваних компонентів крони характеризуються гостровершинністю та правосторонньою асиметрією.

Встановлено наявність прямого високого за тіснотою зв'язку у варіантах між фітомасою деревної зелені, фітомасою гілок, фітомасою хвої із показником відносної повноти деревостану.

Як основні аргументи під час побудови математичних моделей оцінки компонентів фітомаси крони сосняків використано середній діаметр, середню висоту та відносну повноту насаджень. Виявлено прямий зв'язок величини компонентів фітомаси крони із середнім діаметром та відносною повнотою деревостану, тоді як із висотою - обернений.

Структурний аналіз фітомаси компонентів крони показав поступове зменшення фітомаси хвої 3 віком деревостанів із відповідним збільшенням у насадженні частки гілок на $5 \%$.

Розроблені нормативні таблиці фітомаси компонентів крони дають змогу збагатити наявну інформаційну базу та $є$ основою для оцінювання стану i прогнозування біопродуктивності соснових насаджень в умовах Північного Степу України.

\section{Бібліографічні посилання}

Barthélémy, D., \& Caraglio, Y. (2007). Plant Architecture: A Dynamic, Multilevel and Comprehensive Approach to Plant Form, Structure and Ontogeny. Ann. Bot., 99 (3), 375-407. https:// doi.org/10.1093/aob/mcl260

Basuki, T.M. (2015). Leaf area index derived from hemispherical photograph and its correlation with aboveground forest biomass. Indonesian Journal of Forestry Research., 2 (1), 31-41. https://doi. org/10.20886/ijfr.2015.2.1.31-41

Bilous A.M. (2010). Phytomass of crowns of aspen tree stands of Eastern Polissya of Ukraine. Biological Resources and Nature Management, 2 (1/2), 95-99. (in Ukrainian).

Faraway, J.J. (2016). Extending the linear model with $R$ : generalized linear, mixed effects and nonparametric regression models. Series Texts in Statistical Science (vol. 124), Chapman \& Hall/CRC Press, Boca Raton, FL, USA, pp 400. https://doi. org/10.1201/9781315382722

Fernández, M.P., Norero, A., Vera, J., \& Perez, E. (2011). A functional-structural model for radiata 
pine (Pinus radiata) focusing on tree architecture and wood quality. Annals of Botany, 108, 1155-1178. https://doi.org/10.1093/aob/mcr156

Grote, R., \& Reiter, I. M. (2004). Competitiondependent modelling of foliage biomass in forest stands. Trees, 18, 596-607. https://doi.org/10.1007/ s00468-004-0352-9

Goodman, R.C., Phillips, O.L., \& Baker, T.R. (2014). The importance of crown dimensions to improve tropical tree biomass estimates. Ecological Applicatins, 24 (4), 680-698. https://doi. org/10.1890/13-0070.1

Hasenauer, H., \& Monserud, R.A. (1996). A crown ratio model for Austrian forests. Forest Ecology Management, 84 (1-3), 49-60. https://doi. org/10.1016/0378- 1127(96)03768-1

He, Q., Chen, E., An, R., \& Li, Y. (2013). Aboveground biomass and biomass components estimation using LiDAR data in a coniferous forest. Forests, 4, 984-1002. https://doi.org/10.3390/f4040984

Krakau U.K., Liesebach M., Aronen T., LeluWalter M.A., \& Schneck V. (2013). Scots Pine (Pinus sylvestris L.). In: Pâques L. (eds) Forest Tree Breeding in Europe. Managing Forest Ecosystems, 25. Springer, Dordrecht. https://doi. org/10.1007/978-94-007-6146-9_6

Lakyda, P. I. (2002). Live biomass of Ukrainian forests. Ternopil: Zbruch (in Ukrainian).

Lakyda, P. I., \& Matushevich, L. M. (2006). Phytomass of birch forest stands of Ukrainian Polissya. Kyiv: NSC «Institut agrarian economics» (in Ukrainian).

Lakyda, P.I., Matushevich, L.M., \& Blishchik, V.I. (2012). Methodological features of assess of biotic product components crown. Scientific Herald of National University of Life and Environmental Sciences of Ukraine. Series: Forestry and decorative gardening, 171 (2), 54-60 (in Ukrainian).

Lakyda, P. I., Morozyuk, A. V., Shamray, A.E. (2013). Phytomass and carbon deposited of artificial pine stands of Cherkassy pine stands. Forestry and landscape gardening, 3. Access: http://nbuv.gov.ua/ UJRN/licgoc_2013_3_8 (in Ukrainian).

Lakyda, P. I. (2011). Reference materials for estimating components of above-ground live biomass of trees of main forest-forming tree species of Ukraine. Kyiv: Publishing House «EKO-inform» (in Ukrainian).

Mäkelä, A., \& Valentine, H.T. (2006). Crown ratio influences allometric scaling of trees. Ecology, 87, 2967-2972. https://doi.org/10.1890/00129658(2006)87[2967:CRIASI]2.0.CO;2.

Pohjola, J., Laturi, J., Lintunen, J., \& Uusivuori, J. (2018). Immediate and long-run impacts of a forest carbon policy - A market-level assessment with heterogeneous forest owners. Journal of Forest Economics, 32, 94-105. https://doi.org/10.1016/j. jfe.2018.03.001.

Poudel, K.P., Temesgen, H., \& Gray, A.N. (2015). Evaluation of sampling strategies to estimate crown biomass. Forest Ecosystems, 2 (1). 1-11. https://doi. org/10.1186/s40663-014-0025-0
Rogozin, M.V., \& Razin, G.S. (2015). Dynamics models and modeling of tree stand development. Siberian Journal of Forest Science, 2, 55-70 (in Russian with English abstract). https://doi. org/10.15372/SJFS20150205

Tóth, E. G., Köbölkuti, Z.A., Pedryc, A., \& Höhn, M. (2017). Evolutionary history and phylogeography of Scots pine (Pinus sylvestris L.) in Europe based on molecular markers. Journal of Forestry Research, 28 (4), 637-651. https://doi.org/10.1007/s11676017-0393-8

Turski, M., Beker, C., Kaźmierczak, K., \& Najgrakowski, T. (2008). Allometric equations for estimating the mass and volume of fresh assimilational apparatus of standing Scots pine (Pinus sylvestris L.) trees. Forest Ecology and Management, 255 (7), 26782687. doi: $10.1016 /$ j.foreco.2008.01.028

Usoltsev, V.A. (2005). Methods for determining biological productivity of forest stands. Ekaterinburg: Ural State Forest-Technical University Publishing House (in Russian).

Usoltsev V.A. (2007). Biological productivity of Northern Eurasia's forests: Methods, datasets, applications. Yekaterinburg: Ural branch of Russian Academy of sciences (in Russian).

Vass, M.M., \& Elofsson K. (2016). Is forest carbon sequestration at the expense of bioenergy and forest products cost-efficient in EU climate policy to 2050? Journal of forest economics, 24, 82-105. https://doi. org/ 10.1016/j.jfe.2016.04.002

\section{Нормативы оценки продуктивности кроны сосновых древостоев в условиях Северной Степи Украины}

\author{
П.И. Лакида' , В.Н. Ловинская²
}

Биологическая продуктивность лесов рассматривается как их основная характеристика, определяющая ход процессов в лесных экосистемах. Она используется для экологического мониторинга при постоянном ведении лесного хозяйства. Сосна обыкновенная является наиболее распространенным древесным видом, как в масштабах Европы, так и Украины. Учитывая это,

Лакида Петр Иванович - академик Лесной академии наук Украины, профессор, доктор сельскохозяйственных наук, директор учебно-научного института лесного и садово-паркового хозяйства НУБиП Украины. Национальный университет биоресурсов и природопользования Украины, ул. Героев Обороны, 15, г. Киев, 03041, Украина. Тел.: (044) 527-85-28, +38-067462-80-43. E-mail: lakyda@nubip.edu.ua ORCID: http://orcid. org/0000-0003-3639-2969

Ловинская Виктория Николаевна - кандидат биологических наук, доцент кафедры садово-паркового хозяйства. Днепровский государственный аграрно-экономический университет, ул. С. Ефремова, 25, г. Днепр, 49060, Украина. Тел.: +38-067769-63-29; E-mail: glub@ukr.net ORCID: http://orcid.org/ 00000002-7359-9443 
предоставление информации по моделированию биопродуктивности сосновых насаждений в условиях степной зоны Украины является крайне актуальным вопросом.

Объектом исследования стали древостои сосны обыкновенной, произрастающие в условиях Северной Степи Украины. Предмет исследования - биопродуктивность компонентов кроны сосновых древостоев Северной Степи Украины. Цель исследования заключалась в разработке моделей и нормативных таблиц структурных компонентов фитомассы кроны древостоев сосны обыкновенной Северной Степи Украины.

Оценке подлежали сосновые насаждения, сосредоточенные в пределах лесного фонда государственных предприятий Днепровского областного управления лесного и охотничьего хозяйства Днепропетровской области. Во время проведения полевых и лабораторно-камеральных исследований использовали методику проф. П.И. Лакиды.

На основе полученных результатов сформирован рабочий массив данных таксационных показателей с включением среднего диаметра, средней высоты, относительной полноты, а также показателей фитомассы древесной зелени в свежесрубленном состоянии, фитомассы ветвей и фитомассы хвои в абсолютно сухом состоянии для сосновых древостоев.

Статистический анализ показал превышение критических значений асимметрии и эксцесса в случаях распределений как фитомассы древесной зелени, веток, так и хвои древостоев. Обнаружено, что кривые распределений фитомассы всех компонентов кроны характеризуются островершинностью и левосторонней асимметрией.

По результатам корреляционного анализа установлена прямая, высокая степень связи (коэффициент корреляции 0.69-0.74) во всех вариантах между фитомассой компонентов кроны и относительной полнотой насаждения. Коэффициент корреляции средней силы $(r=0.45)$ зафиксирован в случае взаимосвязи фитомассы ветвей древостоя со средним диаметром насаждения.

При моделировании в качестве аргументов регрессионных зависимостей выступали средний диаметр, средняя высота и относительная полнота насаждений. Разработанные математические модели демонстрируют наличие прямой связи между фитомассой любого компонента кроны со средним диаметром и относительной полнотой насаждения. В случае с высотой древостоя, эта связь обратная.

Приведены нормативные таблицы, основное предназначение которых заключается в их использовании для оценки фитомассы компонентов кроны сосновых древостоев с относительными полнотами в пределах от 0,6 до 0,9. Установлено, что фитомасса древесной зелени, веток и хвои древостоев сосны обыкновенной увеличивается при росте средних диаметров насаждений, тогда как при увеличении средних высот она падает.
Анализ фитомассы крон сосняков по структурным частям показал постепенное уменьшение фитомассы хвои с соответствующим ростом части ветвей с возрастом древостоев.

Приведен сравнительный анализ полученных результатов с данными, найденными авторами для древостоев сосны обыкновенной для других природных зон Украины.

Ключевые слова: Pinus sylvestris L.; модель фитомассы древостоя; древесная зелень; ветви; хвоя; Днепропетровская область.

\section{Standards for estimating the crown productivity of pine stands within the conditions of the Northern Steppe of Ukraine}

\author{
P. Lakyda' ${ }^{1}$ V. Lovynska ${ }^{2}$
}

The biological productivity of forests is considered as their main characteristic, which determines the course of processes in forest ecosystems. It is used for ecological monitoring with the constant management of forestry. Scots pine is the most widespread forest species, both on a scale of Europe and Ukraine. With this in view, provision of information on the modeling of bioproductivity of pine plantations in the conditions of the steppe zone of Ukraine is a very topical issue.

The object of the study were the Scots pine stands, which grow in the conditions of the Northern Steppe of Ukraine. The subject of the research was the bioproductivity of the crown components of the Scots pine stands within Northern Steppe of Ukraine. The aim of the research was to develop models and normative tables of structural components of crown biomass of the Scots pine stands within Northern Steppe of Ukraine.

Scots pine stands within forest fund area subordinated to the State Agency of Forest Resources in Dnipropetrovsk region were evaluated. During preparatory field mensuration, and laboratory research stages methodology developed by P.I. Lakyda used.

On the basis of the research results the working mass of data of biometric parameters with inclusion of average diameter, average height, relative density,

Petro Lakyda - full Member of Forestry Academy of Sciences of Ukraine, Professor, Doctor of Agricultural Sciences, Director of Education and Research Institute of Forestry and LandscapePark Management. National University of Life and Environmental Sciences of Ukraine, Heroyiv Oborony st., 15, Kyiv, 03041, Ukraine. Tel.: 044-527-85-28; +38-067-462-80-43. E-mail: lakyda@nubip.edu.ua ORCID: http://orcid.org/0000-0003-36392969

Viktoriia Lovynska - PhD of Biological Sciences, Associate Professor of the Department of Garden and Parks. Dniprovsk State Agrarian and Economic University, S. Yephremova st., 25, Dnipro, 49060, Ukraine. Tel.: +38-067-769-63-29; E-mail: glub@ukr.net ORCID: http://orcid.org/0000-0002-7359-9443 
foliage biomass in fresh state, branches biomass and needles biomass in absolutely dry condition for Scots pine stands are formed.

The statistical analysis showed, that skewness and kurtosis were higher than their critical values in case of distribution foliage biomass, branches biomass and needles biomass of stands. It was found that curves of distribution of biomass of all crown components are characterized by sharpness and left-hand asymmetry.

The data analysis on correlation coefficients showed a straight moderate correlation of branches biomass with the mean diameter of stands $(r=0.45)$, and a significant correlation all components of crown biomass with relative density of stands (from 0.69 to 0.74 ).

During the modelling, the arguments for regression dependencies were the average diameter, average height and relative density of stands. The developed mathematical models demonstrated the presence of a direct link between the biomass of any crown component with a mean diameter and the relative density of stands. In the case of mean height of stands, this connection was inverse.

The normative tables are given, the main purpose of which is to use them to estimate the biomass of crown components of Scots pine stands with relative density in the range from 0.6 to 0.9 . It has been established that foliage biomass, branches biomass and needles biomass in pine stands increase with the growth of average diameter of stands, while with increasing average heights it goes down.

The analysis of Scots pine crown biomass for structural parts revealed a gradual decrease in needles biomass with corresponding increase of branches biomass part with increase stands age.

The comparative analysis of the study results with the data found by the authors for the pine stands another natural zones of Ukraine is presented.

Key words: Pinus sylvestris L.; model of stands biomass; foliage; branches; needles; Dnipropetrovsk region. 